University of Michigan Law School

University of Michigan Law School Scholarship Repository

\title{
Reading One Poet in Light of Another: Herbert and Frost
}

\author{
James Boyd White \\ University of Michigan Law School, jbwhite@umich.edu
}

Available at: https://repository.law.umich.edu/articles/2310

Follow this and additional works at: https://repository.law.umich.edu/articles

Part of the American Literature Commons, and the English Language and Literature Commons

\section{Recommended Citation}

White, James Boyd. "Reading One Poet in Light of Another: Herbert and Frost." In George Herbert in the Nineties: Reflections and Reassessments, edited by J. F. S. Post and S. Gottlieb, 5-80. George Herbert Journal Special Studies \& Monographs, 18. Fairfield, Conn.: George Herbert Journal, 1995. DOI: https://doi.org/10.1353/ghj.1995.0016

This Article is brought to you for free and open access by the Faculty Scholarship at University of Michigan Law School Scholarship Repository. It has been accepted for inclusion in Articles by an authorized administrator of University of Michigan Law School Scholarship Repository. For more information, please contact mlaw.repository@umich.edu. 
JAMES BOYD WHITE

\section{Reading One Poet in Light of Another: Herbert and Frost}

In this paper I wish both to draw certain connections between Herbert and Frost and at the same time to say something in a general way about the process by which such connections can be made. It is with the latter question that I begin.

Once the relation between two writers would have been thought of mainly in terms of "influence." And one might indeed argue that Herbert did have significant influence on Frost's poetic practice - if not directly, for Frost was not a great reader of Herbert, then indirectly, through Emerson, who was in many ways Frost's master and who read Herbert with admiration throughout his life. ${ }^{1}$ But I am not now interested in advancing that line of argument, in part because the more I think about it the less clear I am about what such a claim of influence could really mean.

I wish rather to look at the connections between these poets from the point of view of the reader, as an instance of the way in which one's prior experience of reading shapes one's present responses to a particular text or series of texts. For we cannot help placing what we read in contexts of our own making, defined by our educations; these contexts in turn give meaning to what we read, as certain features are highlighted or obscured by the expectations we have formed. The connections so established can be chronological, as one brings one's reading of Donne, say, to Yeats; or antichronological, as in my own reading of Frost and Herbert, for I was familiar with Frost, who was to me very much the ideal poet, long before I read Herbert with any care.

In this paper, then, I shall briefly approach Herbert with the eyes, or perhaps more properly listen to him with the ears, of one whose sense of poetry was in considerable measure shaped by Frost. 
What I say has an irreducibly autobiographical element, but I do not apologize for this; it is part of my point that all of our readings have such elements and that it would be good to make them more explicit than we often do. The poem is not an abstract art-object to be examined "objectively," after all, but a text made by one mind reaching out to others; and what it means to any one of us is in part shaped by the history of his or her own mind.

In my own case, an important part of this history was the training in reading I received at Amherst College in the late 1950s. ${ }^{2}$ This was a world in which, as I saw it, the English department ruled supreme. English was widely regarded as the most demanding and rewarding field of study, with an almost mystical power, and close to the center of that field was Robert Frost. He was Amherst's poet, we felt: he had actually taught there many years before and he still visited the campus for a week or two every year, and sometimes even more frequently. And he was of New England, at least by transplantation - as we were of New England too, at least by transplantation. More even than Eliot he was the exemplar of what a poet could be. Part of this was his interest in form; part that he seemed to speak in ordinary language, the virtues of which were the subject of the great freshman composition course that transformed the minds of so many of us. Frost could be seen, as Reuben Brower and others argued, as a poet of voices; ${ }^{3}$ and "voice" and "tone of voice" were essential elements of our vocabulary, not only in the reading of poetry, but in thinking about our own writing; for we were taught that in writing we defined ourselves and acted on others, and that writing itself was in this sense a radically ethical activity. The heart of what it has meant for me to come to Herbert by way of Frost, to read Herbert in light of Frost, is that the reading of Frost's poetry of voices has helped me hear the voices in Herbert better.

\section{Differences and Similarities}

There are obvious and profound differences between Herbert and Frost. They write from different parts of the self, to different audiences. Herbert typically speaks out of the central experience of his inner self, to his God or to some version of him. Frost speaks less as a self than as a poet, or The Poet perhaps, and in a way that is far less openly revealing of his inner struggles; and he speaks not to various versions of his God, but to a reader as secure and universal 
as he himself tries to be. Despite his stance as an isolated rural figure, then, Frost works in a much more public and formal idiom than Herbert usually does.

Herbert writes from the inside out, or as Emerson says of him $a b$ intra, ${ }^{4}$ starting with internal experience for which he has no adequate way of talking and trying to make such a language in his verse. The images and metaphors he uses are thus often explicitly marked as efforts to say the unsayable, not arrayed in the form of a story, but connected by movements of imaginative and emotional association. (This is one reason it can be hard to remember his poems accurately.) Frost, by contrast, typically writes from the outside, beginning with a highly visualized event in the natural or social world - the spider on the heal-all, the deer swimming across the pond, the reflection in the surface of a well, the dust of snow falling from a hemlock tree - upon which he then expands, finding meaning within it or claiming meaning for it, almost always against the possibility of no meaning at all. Herbert is in these ways much more like the other Amherst poet, Emily Dickinson, than he is like Frost.

Yet there are important similarities between them as well, and it is with these that I shall here be most concerned. Think, to begin with, of the sentimental way they are both frequently misread: Frost as the country sage producing verse of a greeting card banality, Herbert as the pious Anglican saint, producing verse of sweet devotion. Both of them, properly read, are as far from the sentimentality often attributed to them as could well be imagined: Frost bleak and cold, Herbert terrified and alone, both of them undermining at every stage just the implications of their verse that are seized on in such misreadings.

But these misreadings are not accidental; they have a basis in the verse itself. Part of what misleads the reader in each case is a tendency toward the sententious. In Frost, this shows up as the portentous voice of the Yankee sage uttering wisdom: "Something there is that doesn't love a wall"; "One could do worse than be a swinger of birches." In Herbert the analogous tendency is toward a moralizing sermon voice, seen most completely in "The Church-porch," but appearing throughout his verse: in "Sunday," "Lent," and even in some of the very great poems, as at the ending of "The Flower" and "The Holdfast." What the typical misreading of both poets misses is the degree to which this tendency is made problematic by the verse itself, made the object in fact of sustained criticism. 
A related point is that both poets, in different ways, are interested in the possibilities of plain speech and natural diction: Frost trying to catch the rhythms of ordinary New England speech and cast them into the forms of verse; Herbert obsessed with the thought that the best verse, the best prayer, would be the simplest: "My God, my King"; "My Joy, my life, my crown." Frost incorporates this diction and these rhythms directly into his verse; Herbert does this too, and does it beautifully and naturally - "How fresh, O Lord, how sweet and clean / Are thy returns." Yet, as he makes plain in the "Jordan" poems, he also sees the very simplicity of voice and diction to which he aspires as in some ways inconsistent with his own commitment to poetic form and complexity. Frost sees a somewhat similar opposition between natural and artificial speech - between the "sentence sound," as he calls it, and the demands of meter and rhyme - and makes of this tension a fundamental principle of his art.

Substantively, both of these poets are consumed with what is for them the ultimate metaphysical or theological question: Who - or What - is out there? For Herbert the issue has less to do with the existence of his God, which he in some sense never seems to doubt, ${ }^{6}$ than with his nature or quality: is He a God of Power or a God of Love? Of justice or mercy? What relation, if any, has $\mathrm{He}$ with Herbert, or with his speaker? For Frost the question is superficially less theological than metaphysical: ${ }^{7}$ is the natural world full of fellow feeling, as it seems to the Wordsworthian nature poet in him? Or is it cold, indifferent; random, maybe; or malign? This is the famous question of "Design," and it runs through a great deal of Frost's verse.

Both poets are absolute masters of poetic form, among the greatest in the English language: they both make verse that meets strict and varying formal requirements yet sounds effortless, as though the speaking voice naturally fell into such forms. And in the work of both poets form has a deeply substantive meaning: the very fact that language can be cast in the ordered forms of verse, that the sentence sound can work within the constraints established by the meter, that the right word rhymes with the right word, is for both poets, I believe, one of the strongest arguments, perhaps the strongest argument, that something like grace is at work in the world.

For whatever may be true of the universe more generally, here in the poem is enacted the possibility of order and beauty; and the sources of this order and beauty are found in the world, in the 
materials of language, not simply made up by the poet. In "Paradise," for example, Herbert discovers that he can make a poem in which the last word of the first line of each stanza loses its initial letter in the second, its second letter in the third, and it all works out: "Charm, harm, arm; grow, row, ow; start, tart, art." Or in "Heaven" that the last word of the line can come back, reduced, in an echo that affirms a source of meaning in the language and in the world: "Shall it persever? Ever." But these are only extreme instances of the more ordinary yet still incredible fact that it is possible to think in words that rhyme, in sentences that run in metrical forms. Nothing we know would make this likely, but it is so, a fact of poetry, to which different poets will of course give different meanings. For each of these poets it becomes an affirmation of what he most doubts.

The initial points of comparison I have marked, then, are these: that each poet is susceptible to sentimentalized misreadings; that these misreadings are in sense invited by the poet's tendency towards the sententious, in Herbert's case towards the sermon voice, in Frost's that of the Yankee sage; that each is simultaneously committed to simplicity of thought and diction and to a complex and artificial art that seems - sometimes to the poet himself - inconsistent with it; that each is consumed with the ultimate question of the character of God, or of the universe; and that each poet finds in the possibility of poetry itself perhaps the best ground for a hopeful response to this question.

There is still another point of similarity, related I think to each of the others, which I wish to develop at greater length, namely that both of these poets are self-conscious in the extreme about the ways in which their claims of meaning, their constructions of the universe and themselves, have tendencies towards falsity. While it is true that the possibilities of poetic meaning are a ground of hope for both, it is also true that for both the very act of writing, or speaking, or thinking, is deeply perilous, involving the danger of false feeling and false thought. This fact indeed defines a central subject for both poets.

\section{"I shall be telling this with a sigh"}

My title for this section is taken from Frost's most famous, or infamous, poem, "The Road Not Taken," which has made it into the canon of greeting card and calendar literature. We all know that the poem describes the choice of one path over another in the woods; but 
it is less widely recognized, I think, that it does this in two different and competing ways:

Two roads diverged in a yellow wood, And sorry I could not travel both And be one traveler, long I stood And looked down one as far as I could To where it bent in the undergrowth;

Then took the other, as just as fair, And having perhaps the better claim, Because it was grassy and wanted wear; Though as for that the passing there Had worn them really about the same,

And both that morning equally lay In leaves no step had trodden black. Oh, I kept the first for another day! Yet knowing how way leads on to way, I doubted if I should ever come back.

I shall be telling this with a sigh Somewhere ages and ages hence:

Two roads diverged in a wood, and I I took the one less traveled by, And that has made all the difference.

Notice that when the choice is first represented, the speaker sees no ground for it at all. He simply makes his choice, without any articulated basis for it. Having done this, however, he immediately starts to explain and justify himself, personifying the road and moralizing the choice: he took the second road "as just as fair, / And having perhaps the better claim, / Because it was grassy and wanted wear."

This is the imagining mind at work, claiming or finding or constructing meanings where there are perhaps none at all. The speaker is starting off here on a path, not a real one but a literary one, that will ultimately lead him to a second way of describing his choice, in his imagined portentous and sentimental final statement. But now, at this stage in the process, he can check this tendency and 
return to the careful observation of what is there, recognizing that there is no real difference between the paths.

The voice of realistic, particular, and unselfimportant description thus starts to become one of sentimental and moralistic pretension, but catches itself just in time. But, out of this very experience perhaps, the speaker foresees that the day will come, maybe in old age, when he will no longer catch himself but fall victim to the tendencies of mind he has at once exhibited and resisted, a time when he will claim for himself a false heroic role as a latter-day Thoreau, marching to a different drummer. The sentimentality of the conclusion is marked for us by the heaviness of the repeated "I - I," by the lameness of the concluding word, which does not quite scan - the reader hovers uncomfortably between "differ-ence" and "diff'rence," neither of which is exactly right - and most of all by the prior descriptions of the choice, which falsify the claims being made here. ${ }^{8}$ Yet the power of what I am calling Frost's sentimentalizing voice is so strong as to blur all this for the reader, to carry us as well as him into the land of the Hallmark card. The sentimentality is rejected, yet its uncanny power is at once acknowledged and performed.

With this poem I should like to compare Herbert's well-known "Life," which I think also takes as its subject the delusive power of the speaker's imagination.

I made a posie, while the day ran by:

Here will I smell my remnant out, and tie My life within this band.

But Time did becken to the flowers, and they

By noon most cunningly did steal away, And wither'd in my hand.

My hand was next to them, and then my heart:

I took, without more thinking, in good part

Times gentle admonition:

Who did so sweetly deaths sad taste convey, Making my minde to smell my fatall day;

Yet sugring the suspicion.

Farewell deare flowers, sweetly your time ye spent, Fit, while ye liv'd, for smell or ornament, 
And after death for cures.

I follow straight without complaints or grief, Since if my sent be good, I care not if

It be as short as yours.

The speaker says that he collected some flowers and "made a posie" of them; he did this as "the day ran by" - that is, as a response to, or in acknowledgement of, the passage of time. "Here will I smell my remnant out, and tie / My life within this band." He is attempting to face mortality by constructing this artwork of flowers and merging himself with it. But he sees that he fails. Like Frost's speaker, this one first makes a claim of meaning beyond what the world will bear, then corrects it.

The meaning-claiming side of the mind is not defeated by this, however, but turns it all into a lesson: "My hand was next to them, and then my heart: / I took, without more thinking, in good part / Times gentle admonition." No terror, no anxiety even of the kind implied in "while the day ran by," but a conclusion meant to be comfortable. Defeated in one attempt to face death by an act of imaginative creation, it tries another, turning the death of the flowers into a comfortable sermon.

The suspicion has indeed been highly sugared, as the speaker quickly demonstrates in his farewell to the flowers: "Fit, while ye liv'd for smell or ornament, / And after death for cures," referring both to herbal medicine and to the kind of "cure" of his anxiety that the dying flowers are made by his imagination to achieve. At the end he asserts without conscious conflict his conclusion: "I follow straight without complaints or grief, / Since if my sent be good, I care not if / It be as short as yours."

The farewell to the flowers thus suggests a farewell of another kind, to himself, but even this is made harmless by the speaker's capacity to formulate its meaning in a benign way. Yet the poem gives it all away with the powerful "if": "if my sent be good." This explicit conditional invites consideration of the other possibility: if it is not good, what then? That is of course the real issue, and the conclusion is far from comfortable. The surface complacency of this ending thus occludes the most likely and most threatening possibility. ${ }^{9}$

The best clue this poem offers to its reader is I think the phrase, "without more thinking." This phrase accurately describes the 
speaker's own efforts in making meaning: for in making the posie, in declaring that he will merge with the flowers, in learning from their death a gentle lesson of his own mortality, and in resting at the end in a formulation marked by the poem itself as a false one, in all of this, he is avoiding "more thinking."

Both "The Road Not Taken" and "Life" are thus written against the poet's own tendency to say things that are too easy, which in one sense or another he knows to be false: in the Frost poem the speaker is on the edge of self-consciousness, almost but not quite realizing the degree to which he will delude himself, while in the Herbert poem the speaker seems to be unaware of his performed self-delusion. But in both cases the poem itself makes the reader aware of what the speaker sees either dimly or not at all, inducing by a kind of structural irony a self-consciousness in the reader - "more thinking" - that it is one of the aims of the poem to create.

\section{Sage Voices}

The voice that Frost resists in "The Road Not Taken" may be his most characteristic one, that of the Yankee sage. It runs throughout his verse, sometimes under control, sometimes not. Think of "Birches," with its image of the boy climbing the birch to swing it to earth again. "I'd like to get away from earth awhile / And then come back to it again and begin over. ... One could do worse than be a swinger of birches." Or of "Directive," the poem about finding the Holy Grail and oneself: "And if you're lost enough to find yourself / By now ..." Or of "Two Tramps in Mudtime," where the speaker reflects on the difference between woodchopping for him, as pleasure, and the paying job it is for the two tramps, from whom he cannot morally take it: "My object in living is to unite / My avocation and my vocation, / As my two eyes make one in sight." Or in "Mending Wall": "Before I built a wall I'd ask to know / What I was walling in or walling out, / And to whom I was like to give offense. / Something there is that doesn't love a wall." And so forth.

As I say, this voice is Frost's most characteristic one, a kind of declaiming; yet the poetry commonly takes it, and its flaws, as one of its central subjects. It is repeatedly subject to criticism. For example, in "Mending Wall," the voice just quoted is answered by another, "Good fences make good neighbors"; the voices limit each other in their mutual response. And in "West Running Brook," the 
man's somewhat long-winded theoretical speech about the meaning of the brook is answered by his wife, in quite another key. Sometimes Frost himself gets swept away by it, as he foresees he will in "The Road Not Taken."

There is still another dimension to the puzzle, which is that in such phrases as I have quoted there is both truth and force. We remember them: however true the criticism, there is truth in the criticized as well. The issue is thus more complex than I have yet proposed, and I will return below to the ways in which Frost works on it.

But first I wish to say a brief word about the analogue in Herbert to Frost's voice of Yankee wisdom, namely what I have called his sermon voice. The strongest and clearest version of this voice is in "The Church-porch," which consists mainly of advice cast in quite conventional terms from an older to a younger man, but versions of it appear throughout his verse. This voice of doctrinal and moral truth is deeply problematic for Herbert. From one point of view what it says is true, nothing truer; it represents the truths which Herbert struggles to accept and to which he refers, in Walton's account, when he describes his verse as representing the "spiritual conflicts" between his soul and his God. From another point of view, however, his verse shows that virtually nothing that is true can be said in such a voice, in such language; the real truth lies in the inadequacy of all our languages, mirroring the inadequacy of the human mind and heart. " "Thy word is all, if we could spell" ("The Flower"). The truth of our situation can be captured, if at all, only in the tension-ridden and evanescent verse he writes at his best, not in any kind of declamation. The sermon voice is wrong in another way too, theologically, for it is by nature authoritarian and punitive, and it represents a God who is those things too. Herbert's deepest struggles will accordingly be not with the God so defined, his "bad" against God's "good," but with his own tendencies to use a voice of doctrinal and moral truth to define his God as authoritarian and remote, against a truth he also sees, that he is a God of love.

In what follows I shall try to give content to these brief remarks about Herbert's sermon voice and its analogue in Frost. For the moment let me just suggest that of neither poet can we say that the verse reflects in some direct way the thoughts or feelings of an integrated self. Rather, for both, poetry expresses the workings of a divided self, in a language that is itself problematic. The poetry has 
as an essential part of its subject the way the speaker can go wrong in writing it, and go wrong not merely aesthetically but at the center of his being and imagination.

\section{"If design govern"}

For Frost the perils of sentimentality and false sagacity are not merely personal, as one might think from "The Road Not Taken," but have theological or metaphysical significance. His poetic reflections on his own tendencies towards falseness become a way of reflecting on the universe itself, of asking whether it actually has the kind of meaning we constantly attribute to it, or is by contrast mute and meaningless.

Take as an example his poem, "Range-finding."

The battle rent a cobweb diamond-strung And cut a flower beside a ground bird's nest Before it stained a single human breast.

The stricken flower bent double and so hung. And still the bird revisited her young.

A butterfly its fall had dispossessed,

A moment sought in air his flower of rest, Then lightly stooped to it and fluttering clung.

On the bare upland pasture there had spread O'ernight 'twixt mullein stalks a wheel of thread And straining cables wet with silver dew.

A sudden passing bullet shook it dry. The indwelling spider ran to greet the fly, But finding nothing, sullenly withdrew.

This poem begins with the speaker extending his imaginative sympathy to the world. This gesture draws attention to the double pathos of the situation, in which damage is done first to sentient nature by thoughtless man, followed by much worse damage to a "human breast." The whole trope depends upon the speaker's sympathy for nature, which implies a reciprocal return, a community of sympathy between man and nature: "The stricken flower bent double and so hung."

But the next line begins to suggest a doubt: "And still the bird revisited her young." From one point of view this is charged with 
feeling, as we imagine the bird, like a human mother, still managing to live in the wreckage of battle; yet there is another possibility, that the bird is simply indifferent to the destruction. The next actor, the butterfly, first pathetically seeks "in air his flower of rest," the flower that has been destroyed by the bullet, but he quickly recovers: "Then lightly stooped to it and fluttering clung." The death of the flower and by implication of more than the flower, the human breast - is of no real moment to him after all.

The speaker has been imagining this scene on the assumption common in romantic poetry, that we live in a world of mutual fellow-feeling; it is the resonance of the fall of the flower, or the man, in the feelings of others, that gives it its meaning. But as he writes another possibility emerges, that these assumptions are simply false, false and sentimental.

The last half of the poem responds to this discovery in two ways: first by speaking of the world of nature in a distant and impersonal way: "On the bare upland pasture there had spread / O'ernight twixt mullein stalks a wheel of thread / And straining cables wet with silver dew." The speaker here no longer represents nature as human and comprehensible, but as an apparently unmotivated external process, as though it were as remote as science makes it. Then, as the phrase "straining cables" begins to suggest, he shifts again, personifying nature once more, making it like us. But this time it is not benign and kindly, but like us in its malignity: "A sudden passing bullet shook it dry. / The indwelling spider ran to greet the fly, / But finding nothing, sullenly withdrew." The tearing bullet, which will kill a man, has been reduced to "nothing."

This poem catches the mind's struggles with its own inclinations and formulations, first trying to see the world as a web of sympathy, then correcting that to distant indifference, then in turn correcting that to malignity. The poem finds no place of rest among these formulations, but presents them as alternate and unsatisfactory possibilities. The movement of the poem is toward this aspect of the truth of our situation.

A similar tension is at work in many of Frost's poems, for example the well-known "Design," which begins in a sense where "Range-finding" leaves off, with a creature that is both endearingly human - "dimpled" - and repulsive: "I found a dimpled spider, fat and white." The question with which the speaker concludes is the question of order and meaning in the universe: "What brought the 
kindred spider to that height, / Then steered the white moth thither in the night? / What but design of darkness to appall - / If design govern in a thing so small." The alternatives the speaker considers are that nature is malign, governed by evil design, or that it has no order, no meaning at all, at least in any matter as small as this. He does not even consider the possibility with which "Range-finding" begins, of a community of sympathy. The point of the poem is not that one alternative is true, the other not, but that our situation is one in which we cannot help thinking in these ways, both of them, each of which is answered by the other."

In "The Most of It" the speaker watches a living being crash into the water on the other side of the lake and swim towards him. He sees in this event an embodiment of the idea that nature lives and is concerned with him, that it reaches out to him, as fellow to fellow - as though he expects his creature to join him as his secret sharer. But it is after all only a deer, who "stumbled through the rocks with horny tread / And forced the underbrush - and that was all." The imagined fellow-feeling dissolves into brute fact and force.

By now Frost has brought us a long way from the problem of sentimentality as I originally defined it, for to speak of the "sentimental" assumes that there is another, unsentimental and true, alternative: that the paths really were the same, and no choice worthy of the name could be made between them, for example, or that the spider is truly indifferent or malign. But in the series of poems just mentioned, there is no such alternative. The truth is that we are caught between, or among, languages that are all unsatisfactory. Even the denial of meaning does not work. When the speaker in "The Most of It" concludes "and that was all," for example, he contradicts himself, for in addition to that dismissive phrase there is the poem itself, shaped and ordered, which in its own compass enacts the very possibilities of meaning he seems to deny.

The point, then, is not simply that we are given to false sentimentalities, but that the very process of imagination at the center of our minds simultaneously deludes and creates. A claim of meaninglessness can be as sentimental as a claim of universal fellow feeling, as incomplete and false. No language is adequate to the meaning of events in the world; the closest thing to adequacy we can have is a poetry which locates us in the tension between our own deepest commitments and our deepest uncertainties.

The attribution of meaning to nature or to the universe is not 
simply a foolishness, an error from which we can extricate ourselves by thinking, or by writing poetry, but as deep a tendency as exists in human nature. Frost's poetry of doubt affirms after all its own processes of imagination and creation. We are caught between two impulses: on the one hand, to see meaning in the world, to find it and claim it, and on the other to doubt, not to see it, or to see meaninglessness. It is not that one is true and the other false, one inherently sentimental, the other inherently factual: we are simply in the situation in which two truths, two tendencies of our nature, both exist with equal force and reality.

But how is it possible to think this double way, and how can it be good? As one analogy I have thought of what we would hope that a person running for President would think about the importance of his campaign and election. To run at all, he has to think that it matters supremely who will be elected, that his administration will do better than any other - that the election, in Frost's language, will "make all the difference." But if he believed this purely, one hundred percent, he would be insane; at the same time that he believes it, then, we want him not to believe it, to realize that his contribution will be small, that the other candidate may not be so bad, that he will face lots of situations in which there is no good choice at all, and so on. Yet if he believed only this, he could never run for president.

Much the same thing could be said about our engagement in other essential but impossible activities: in voting, in teaching our classes, in writing our books, even in starting out on our marriages. It is not that we should have a balanced view, midpoint between extremes; but that both of the competing voices should be loud within us, in a full-throated way, though varying their relation from moment to moment: the voice that says that we can do it and that it really matters, and the one that says that we are caught up in processes beyond our control and understanding.

This doubleness is a form of moral and psychological maturity, towards which Frost's verse leads him and his reader. What it catches, and makes the topic of explicit thought, is the radical tension in human life between the claims of meaning and nonmeaning. Frost works out of a set of uncertainties about the world, himself and his language, that he cannot resolve; but he expresses this irresolution in an activity that makes the irresolution itself both conscious and explicit. Poetry is a necessity for this mind, an integral part of its life; not something he chooses to do, but what existence means for him. 


\section{"And Art thou grieved?"}

About Herbert I shall be much more brief. First, as I said earlier, Herbert is consumed with a cosmic question, as Frost is, though for Herbert the issue is more theological than metaphysical: Who is this God? A God of Power or a God of Love? And who is Herbert in relation to him: a creature to be punished for his sins? One to be made to suffer by whim? Or is he the object of love, and his suffering really a kind of gift? Or is he simply nothing at all to this figure, "a crumme of dust" ("The Temper" [I])? All of these possibilities and more are enacted in Herbert's verse: think of the punitive God of "Justice" (II), for example, the incomprehensible God of "Justice" (I), the God who forbids him to worship the beauty of Mary and the angels in "To all Angels and Saints," the remote God of "The Storm," the loving presence of the interlocutor in "Love" (III), and so on. Herbert himself is sometimes the sententious moralist or doctrinaire theologian, sometimes the broken soul, sometimes the courtier or art-poet, sometimes full of ambition or pride at his achievements, sometimes raked with self-abuse.

Second, again like Frost, Herbert takes as his subject the perils and defects of the very poetic processes by which he pursues these ultimate questions of identity and relation. Herbert's speakers too go wrong, all the time and in a thousand ways, and his verse is in large part about the ways in which they do so. Yet the heart of the problem for him is even deeper in the self than it is for Frost. One reason is a radical epistemic uncertainty: he cannot be sure of what he seems most to know. Think, for example, of "Affliction" (I), where the speaker restates the story of his life (which is also of course a version of Herbert's own). As he tells it, in the only terms available to him, the story begins in happiness and ends in misery. It is a story of affliction, moving from joy to pain. But, as the poem also makes plain, to speak this way is to misrepresent the nature of his experience. The pleasure - "At first thou gav'st me milk and sweetnesses; / I had my wish and way" - confirmed him in a kind of infantile self-centeredness; the pain helped him escape from it. And his difficulty is not only epistemic: as one who thinks in terms of joy and pain, loss and gain - as we all do; as we all must do Herbert's speaker is asserting the priority of his own will and preference over his Lord's. As "The Flower" also suggests, to live is to $\sin$. 
In this, and in many of his poems, Herbert demonstrates a radical uncertainty about his capacity both to perceive and desire correctly. He cannot trust his perceptions, his feelings, or his language. ${ }^{12}$ His poetry addresses these uncertainties in the self and in the universe by making them his explicit subject, all in an effort at selftransformation. This is the aim, for example, of "Affliction" (I) itself: to carry him from the language of joy and pain to another kind of gesture, all that is available when the will has been stripped away: "Ah my dear God! Though I am clean forgot, / Let me not love thee, if I love thee not." The affliction of which the speaker complains reduces him to the core of his being, the last thing he can give up; but this turns out to be his capacity for love, the best thing in him. The reduction of which he complains is thus in a sense a benign one, a healing transformation. ${ }^{13}$

But the transformations worked by his poetry are not always of this kind. Sometimes they are incomplete, as in "Love unknown," where the speaker's interlocutor tells him the truth but he himself cannot quite see it. Sometimes there is a transformation, but it is in the wrong direction: think of "Sepulchre," for example, which begins with a gesture of natural and authentic sympathy - "O blessed bodie, whither art thou thrown? / No lodging for thee, but a cold hard stone?" - and ends somewhat grimly, locating love not in his heart, as it begins, but outside it. "The Temper" manifests two contrary tendencies, in a kind of double transformation. It begins with a sense of helplessness, as the speaker feels himself swung from heaven to hell; moves next into a question, Why do you do this to me? - "Wilt thou meet arms with man?" - then into a prayer, that the speaker be allowed to "roost and nestle" in his Lord's protection. His initial sense of puzzle and distress is first transformed into a challenge to his Lord; this in turn frees him to express his dependency as a species of trust:

Yet take thy way; for sure thy way is best:

Stretch or contract me, thy poore debter:

This is but tuning of my breast,

To make the musick better.

He concludes with a moment of imagined felicity: "Thy power and love, my love and trust / Make one place ev'ry where."

But in this very gesture he claims a kind of equality with God - 
"Thy power and love, my love and trust" - that cannot be stable; and the beginning of "The Temper" (II), which follows next, undoes the whole thing:

It cannot be. Where is that mightie joy, Which just now took up all my heart?

Herbert's verse, like Frost's, is a way of dealing simultaneously with his radical uncertainty about the nature of the universe, and its God, and with his awareness of his own capacities for self-delusion. For both writers poetry is a method of thought and self-correction, in Herbert more than Frost a method of self-transformation; and for both this method is unreliable. It may lead the poet into claiming meaning where there is none, or denying it where there is. But in Herbert the second possibility is especially present: the danger that he will claim no meaning where meaning exists, or a false meaning, or that he will depreciate himself beyond what the truth requires. ${ }^{14}$

Consider, for example, "To all Angels and Saints," where the speaker explains his refusal to adore the beauty and gentleness of Mary and the saints by saying that his "King" forbids it. He thus defines his God as a source of power and justice only, a will that simply must be obeyed. He strips from him, and gives to Mary and the saints and angels, divine qualities of kindness and love, thus constructing the deity to fit with his own need for a punitive power in the world. Likewise, in "Decay" the speaker describes the course of theological history as a decline from the "sweet dayes" when "thou didst lodge with Lot" and were present in the world "at some fair oak, or bush, or cave, or well." Now, by contrast, "thou dost thyself immure and close / In some one corner of a feeble heart." You shrink into the heart, that is, and risk defeat at the hands of sin. For the speaker this is the story, as the title suggests, of decay; but for the reader it is the story of progress, of God's move inward, into the heart, where his momentary defeat at the hands of sin will ultimately be a triumph of love. The self-delusion here, and in "Love unknown" as well, lies in failing to see the positive meaning of the story he tells; in this context the denial of meaning is a denial of his God as well.

"Whitsunday" presents the same issue. It begins, as so many poems do, with a touching gesture or prayer: 
Listen sweet Dove unto my song,

And spread thy golden wings in me;

Hatching my tender heart so long, Till it get wing, and flie away with thee.

The speaker here asks to be entered, and hatched, and seeks to "flie away with thee," in all of this, expressing a remarkable degree of confidence and trust. But this doesn't happen, or not instantly; he then recoils, and universalizes his situation: "Where is that fire which once descended / On thy Apostles?" Once the stars and sun did joyful obeisance to the spirit: "The starres were coming down to know / If they might mend their wages, and serve here." But you have withdrawn: "Thou shutt'st the doore, and keep'st within."

In making this claim the poem actually contradicts what is for Herbert a theological truth, that the Spirit was sent by Christ, when he ascended, to take his place among us, permanently. In this sense the speaker denies the reality, or at least the presence, of the Person to whom he is praying, apparently because his prayer was not instantly answered in a way he could perceive. At the end of the poem he recoils once more, this time from his unconscious denial into a language of doctrinal assertion that is in this context impossible:

Lord, though we change, thou art the same;

The same sweet God of love and light:

Restore this day, for thy great name,

Unto his ancient and miraculous right.

But as he tells the story, it is "God" in his poem who changes, not "we"; and, as defined in this poem, he is no "sweet God of love and light," to say the least. The trust and confidence and authenticity are gone; the speaker has collapsed into doctrine: and the effect of the whole, like "Decay," is to deny the meaning of the very story he tells.

Or so I say. Who am I, you may well ask, to assert the existence of a correct understanding of things from which Herbert's speaker's is a deviation? How can that be a sensible response to a poet who makes as vivid as he does his sense of the uncertainty of his own perceptions, feelings, and language? Presumably not by invoking the language of doctrine, which would simply be another version of his sermon voice. How then? 
Here we are at the center of Herbert's verse. It is, I believe, our own experience of this poetry, of this mind - our experience of reading, responding, and judging - that enables us to make such judgments with a kind of confidence that Herbert himself almost never attains, judgments especially about his loveability, and hence about the possibilities for love in the world.

In reading these poems, as I have suggested, we often find that we seem to know better than the speaker does. This sense of our own knowledge is confirmed when it helps us to read what follows better, disconfirmed when it does not. As we read, we thus learn the language in which the poems are composed, which they half-create. Inhabiting that language, we use it to make sense of what we read, finding that we can explain what before was opaque; this confirms in us a sense of our capacity to find meaning in the world. This is not merely a matter of analytic understanding; through interaction with the world that Herbert creates and the person he is in his verse we undergo slow transformations of our own. It is because it at last speaks for us, saying what in some sense we know from this reading to be true - true for Herbert and in the world that he has created — that "Love" (III) has the incredible power it does.

Like Frost's, Herbert's poetry is written out of sense of its own impossibility and necessity. The sources of impossibility are in the self, in the language, and in the imperfect knowability of the deity, to whom and about whom he speaks. There is no pure heart, no simple speech, no unflawed human action. All we have is the possibility of this kind of poetry. Again as with Frost, this comes from the center of his life. This poetry is the struggle of existence for him.

For both poets the greatest source of hope and confidence in the world lies in this activity, in the possibilities for beauty and form that it offers - and for truth too, of the special kind that interests both, namely movement toward greater recognition of the truth of our situation, where there are no nonproblematic statements of what is true, or none available to us. With Frost this takes the form of the miracle that his words, cast in sentences of meaning, are also meters and rhymes, and the further miracle that there is, sometimes at least, a tension between two orders, that of the sentence and that of the poem, which creates a new kind of life. The meaning of the poem is its voices. As he once said in an interview, you can hear people talking through a wall and know something of what they are saying 
from the tone of the sentence itself, even when you miss the words. ${ }^{15}$ I have a sense that this is how he hears his own verse, as though in its sounds are meanings that have their source elsewhere. Something the same is true of Herbert as well, as "Paradise" and "Heaven" indicate, and the wonderful rhymes at the end of "Deniall" and "A true Hymne." Of both poets we can say that it is the point of their poetry to bring us into the presence of sources of meaning beyond our understanding. ${ }^{16}$

\section{Notes}

'One interested in establishing such "influence" might point to the similar rhyme-patterns of "The Collar" and "After Apple Picking"; to the thematic similarity of the "The Storm" and "Tree at My Window"; and the closing phrases of "Prayer" (I) - "something understood" - and of Frost's sonnet, given its title by these words, "for once then something." On Emerson and Herbert, see Michael J. Colacurcio, " "The Corn and the Wine': Emerson and the Example of Herbert," Nineteenth-Century Literature, 42 (1987), 1-28.

${ }^{2}$ For another account of that world, see Richard Poirier, Poetry and Pragmatism (Cambridge: Harvard Univ. Press, 1992), chapter 4.

${ }^{3}$ See Reuben A. Brower, Robert Frost: Constellations of Intention (New York: Oxford Univ. Press, 1963).

${ }^{4}$ Ralph Waldo Emerson, The Journals and Miscellaneous Notebooks (Cambridge: Belknap Press, 1969), 7:157.

${ }^{5}$ All quotations from Herbert and Frost will be from the following editions: The Works of George Herbert, ed. F.E. Hutchinson (1941; corr. rpt. Oxford: Clarendon Press, 1945); and The Poetry of Robert Frost, ed. Edward Connery Lathem (New York: Holt, Rinehart, and Winston, 1969).

${ }^{6}$ Though in some poems, such as "The Search," the possibility is presented that God is so remote that he might as well not exist.

'But see "A Masque of Reason" and "A Masque of Mercy."

${ }^{8}$ Earlier the same voice made another sentimentalizing gesture, which was also checked: "Oh, I kept the first for another day!" This is a claim that the choice is no choice, that he can always come back; but it is followed by an acknowledgment of reality: "Yet knowing how way leads on to way, / I doubted if I should ever come back."

"Recall the ending of "Vertue," where, apparently in consolation for the loss and death found in the natural world, the speaker says: "Onely a sweet and vertuous soul / Like season'd timber never gives; / But though the whole world turn to coal, / Then chiefly lives." The speaker, caught up in his 
satisfactory theologizing, glides over a question the poet presents us with: what of the soul that is not "sweet and vertuous"?

${ }^{10}$ There is an exception of a kind: presumably for Herbert the language of the Bible, and of the prayer book, are adequate for the purposes for which they are composed. But this does not change the point, for we can use those languages only as readers not writers. One cannot simply adopt them when writing a poem or a letter or a sermon, for now they become ours, and flawed as we are flawed. There are moments in Herbert where he seems to have achieved a sense of adequacy of expression, as in "The Call" and perhaps the end of "The Temper" (I). But this is not a position he can maintain from poem to poem. It is no sooner attained, than it is lost.

${ }^{11} \mathrm{~A}$ more amusing version appears in "The White-Tailed Hornet," in which the speaker describes the way in which, when you disturb it in a barn, the hornet with unerring instinct stings you on the most sensitive place on your nose, thus demonstrating the competence of nature, the effectiveness of natural selection, and hence the order of the universe. Yet on another occasion, the story is wholly different, as are its cosmic implications: in your house, the hornet is lost and awkward, unable to do what it was made to do, suggesting a kind of randomness and radical incompetence in the natural world itself.

${ }^{12}$ Thus "The Holdfast" strips from the speaker the possibility of any action, any claim, even the claim of impotence; leaving him with an inadequate phrase, "that all things were more ours by being his," which at one level makes no sense, at another asserts afresh just the self-interest the poem is supposedly written against. Or think of Herbert's translation of Psalm 23, which is normally read as one of the great expressions of trust in our literature. This is what Herbert says: "The God of love my shepherd is, / And he that doth me feed: / While he is mine, and I am his, / What can I want or need?" Herbert converts the psalmist's gesture of simple trust into a question, apparently with only one possible answer - "nothing." But the question is rendered real by the half-stated conditional: "While he is mine ..." And what happens when I am no longer his? The central terms here, "mine" and "his," though essential to human thought, necessarily assert the distinction between self and God. They are undone, not so much by this poem as by others: "The Clasping of Hands," for example, which chimes "mine" and "thine" until they seem to merge in a loss of identity.

${ }^{13}$ For similar instances, think of "The Thanksgiving," where the poetspeaker is brought at the end to recognize the limits of his art, in a breakdown of the will and mind that is at once a collapse and an achievement; of "Gratefulness," in which the speaker of a simple prayer first feels it to be manipulative, and works his way afresh through the situation, enabling him to speak at the end in a way he could not at the beginning; of "Christmas," where the ordinary narrator's voice becomes capable of a song of praise and love; and so on. 
${ }^{14} \mathrm{Just}$ because "The Temper" (II) comes second does not mean that it is right: the effect of the two poems is to leave the reader and the speaker poised between alternatives.

${ }^{15}$ Robert Frost, "Robert Frost, New American Poet," in Elaine Barry, ed., Robert Frost on Writing (New Brunswick: Rutgers Univ. Press, 1973), pp. 152-53.

${ }^{16}$ Parts of this essay are drawn from my recent book, "This Book of Starres": Learning to Read George Herbert (Ann Arbor: Univ. of Michigan Press, 1994), with the kind permission of the publisher. I am grateful to Sidney Gottlieb, Jonathan Post, Michael Schoenfeldt, and Helen Vendler for helpful comments on an earlier draft. 